Chapman University

Chapman University Digital Commons

Pharmacy Faculty Articles and Research

School of Pharmacy

2011

\title{
3-Substitued Indoles: One Pot Synthesis and Evaluation of Anticancer and Src Kinase Inhibitory Activities
}

\author{
V. Kameshwara Rao \\ Birla Institute of Technology and Science (BITS) \\ Bhupender S. Chhikara \\ University of Rhode Island \\ Amir Nasrolahi Shirazi \\ Chapman University, shirazi@chapman.edu \\ Rakesh Tiwari \\ Chapman University, tiwari@chapman.edu \\ Keykavous Parang \\ Chapman University, parang@chapman.edu \\ See next page for additional authors
}

Follow this and additional works at: http://digitalcommons.chapman.edu/pharmacy_articles

Part of the Chemicals and Drugs Commons, Medical Biochemistry Commons, Medicinal and Pharmaceutical Chemistry Commons, and the Oncology Commons

\section{Recommended Citation}

Rao, V. Kameshwara, et al. "3-Substitued indoles: one-pot synthesis and evaluation of anticancer and Src kinase inhibitory activities." Bioorganic \& medicinal chemistry letters 21.12 (2011): 3511-3514. doi: 10.1016/j.bmcl.2011.05.010

This Article is brought to you for free and open access by the School of Pharmacy at Chapman University Digital Commons. It has been accepted for inclusion in Pharmacy Faculty Articles and Research by an authorized administrator of Chapman University Digital Commons. For more information, please contact laughtin@chapman.edu. 


\section{3-Substitued Indoles: One Pot Synthesis and Evaluation of Anticancer and Src Kinase Inhibitory Activities}

\section{Comments}

NOTICE: this is the author's version of a work that was accepted for publication in Bioorganic \& Medicinal Chemistry Letters. Changes resulting from the publishing process, such as peer review, editing, corrections, structural formatting, and other quality control mechanisms may not be reflected in this document. Changes may have been made to this work since it was submitted for publication. A definitive version was subsequently published in Bioorganic \& Medicinal Chemistry Letters, volume 21, issue 12, in 2011. DOI: 10.1016/

j.bmcl.2011.05.010

The Creative Commons license below applies only to this version of the article.

\section{Creative Commons License}

\section{(c) $10 \Theta \Theta$}

This work is licensed under a Creative Commons Attribution-Noncommercial-No Derivative Works 4.0 License.

\section{Copyright}

Elsevier

\section{Authors}

V. Kameshwara Rao, Bhupender S. Chhikara, Amir Nasrolahi Shirazi, Rakesh Tiwari, Keykavous Parang, and Anil Kumar 


\title{
3-Substitued indoles: One pot synthesis and evaluation of anticancer and Src kinase inhibitory activities
}

\author{
V. Kameshwara Rao, ${ }^{a}$ Bhupender S. Chhikara, ${ }^{\mathrm{b}}$ Amir Nasrolahi Shirazi, ${ }^{\mathrm{b}}$ Rakesh \\ Tiwari, ${ }^{\mathrm{b}}$ Keykavous Parang, ${ }^{\text {,** }}$ Anil Kumar, \\ ${ }^{a}$ Department of Chemistry, Birla Institute of Technology and Science, Pilani 333 031, Rajasthan, India \\ ${ }^{b}$ Department of Biomedical and Pharmaceutical Sciences, College of Pharmacy, University of Rhode Island, Kingston, RI \\ 02881, USA
}

This is where the receipt/accepted dates will go; Received Month XX, 2000; Accepted Month XX, 2000 [BMCL RECEIPT]

\begin{abstract}
An efficient and economical method was developed for the synthesis of 3-substituted indoles by one pot three-component coupling reaction of a substituted or unsubstituted benzaldehyde, $\mathrm{N}$-methylaniline, and indole or $\mathrm{N}$-methylindole using $\mathrm{Yb}(\mathrm{OTf})_{3}-\mathrm{SiO}{ }_{2}$ as a catalyst. All the synthesized compounds were evaluated for inhibition of cell proliferation of human colon carcinoma (HT-29), human ovarian adenocarcinoma (SK-OV-3), and $c$-Src kinase activity. The 4-methylphenyl (4o and 4p) and 4-methoxyphenyl (4q) indole derivatives inhibited the cell proliferation of SK-OV-3 and HT-29 cells by 70-77\% at a concentration of $50 \mu \mathrm{M}$. The unsubstituted phenyl (4d) and 3-nitrophenyl (4l) derivatives showed the inhibition of c-Src kinase with $\mathrm{IC}_{50}$ values of $50.6 \mu \mathrm{M}$ and $58.3 \mu \mathrm{M}$, respectively.
\end{abstract}

The 3-substituted indoles are structural units of many natural and biologically interesting compounds, which possess various pharmacological activities. ${ }^{1-4}$ The indole derivatives serve as a scaffold in a number of antibacterial, ${ }^{5}$ antiviral, ${ }^{6}$ and protein kinase inhibitors. $^{7}$ Indole-based derivatives have been investigated for anticancer activities. Indole-3-carbinols have been previously reported to exhibit anticancer activities against a number of human cancers through acting on different cellular signaling pathways. ${ }^{8}$ 1Aroylindoles and 3-aroylindoles have shown potent cytotoxicity against different human cancer cell lines. ${ }^{9}$

Several indole derivatives have shown tyrosine kinase inhibition in low micromolar range. ${ }^{7,10} 3$ Substituted 2,2'-dithiobis( $1 H$-indoles) have been reported to show inhibition against protein tyrosine kinases (PTKs), such as EGFR and non receptor v-Src tyrosine kinases. ${ }^{11}$ SU5416 (Fig. 1) is an indole-based FIK-1/KDR inhibitor, and is currently in clinical trials against ovarian cancer. ${ }^{12-14}$

The Src family of tyrosine kinases (SFKs) is comprised of nine tyrosine kinases viz., Src, Lck, Fyn, Yes, Hck, Blk, Fgr, Lyn, and Yrk. SFKs have critical roles in multiple signaling pathways that control a diverse spectrum of biological activities, such as growth factor signaling, cell growth, division, differentiation, survival, adhesion, migration, and invasion. ${ }^{16} \mathrm{c}-\mathrm{Src}$ tyrosine kinase is the prototype of SFKs. c-Src upregulation has been observed in a number of epithelial tumors, such as ovary, colon, lung, breast, prostate, and pancreas when compared with the normal tissues. c-Src serves as a key modulator of cancer cell invasion and metastasis through reducing cell adhesion and facilitating motility. ${ }^{17-19}$ Thus, considerable interest has been evolved around the design of Src kinase inhibitors for the treatment of cancer and anti-invasion therapy. ${ }^{20} \mathrm{~A}$ number of small molecule inhibitors ${ }^{21-22}$ have shown potential biological activity as both antiproliferative and anti-invasive agents in preclinical studies in different solid tumor types. ${ }^{23-26}$<smiles>Cc1cc(C)c(/C=C2\C(=O)Nc3ccccc32)[nH]1</smiles>

Figure 1. Chemical structure of SU5416.

In continuation of our efforts towards the development of organic transformations catalyzed by metal triflates ${ }^{27}$ and synthesis of small molecules as anticancer agents and/or c-Src kinase inhibitors, ${ }^{15,28}$ herein we report an expeditious one-pot synthesis of 3substituted indoles by three component condensation catalyzed by $\mathrm{Yb}(\mathrm{OTf})_{3}-\mathrm{SiO}_{2}$ (Scheme 1$)$ and evaluation of their anticancer and c-Src kinase inhibitory activity.

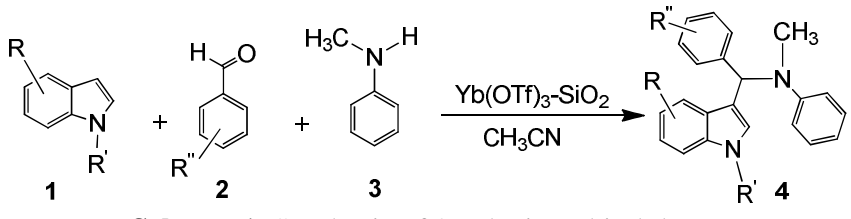

Scheme 1. Synthesis of 3-substituted indoles.

The 3-indole derivatives were synthesized by one pot condensation reaction of indole or $\mathrm{N}$-methylindole, a substituted or unsubstituted benzaldehyde, and $\mathrm{N}$ methylaniline. The reaction condition optimizations were performed by monitoring a model reaction between indole, 4-chlorobenzaldehyde and $\mathrm{N}$ - 
methylaniline. The model reaction was carried out in various solvents, such as DCM, DMSO, DMF, THF, acetonitrile, and ionic liquid $[\mathrm{bmim}]\left[\mathrm{BF}_{4}\right]$, using $\mathrm{Yb}(\mathrm{OTf})_{3}-\mathrm{SiO}_{2}$ as a catalyst. Among these solvents acetonitrile was found to be most efficient reaction media to give $\mathbf{4 a}$ in good yield (88\%) while the reaction yield in other solvents was very poor.

Furthermore, catalyst conditions were optimized by using different variations of catalyst, catalyst loading, and time period of reaction (Table 1). The yield of $\mathbf{4 a}$ was poor and required longer time when reaction was performed with either $\mathrm{Yb}(\mathrm{OTf})_{3}$ or silica gel alone. Among the screened catalysts $\mathrm{Yb}(\mathrm{OTf})_{3}-\mathrm{SiO}_{2}(5-10$ mol \%), $\mathrm{Ce}(\mathrm{OTf})_{3}-\mathrm{SiO}_{2}(5 \mathrm{~mol} \%)$, and $\mathrm{Cu}(\mathrm{OTf})_{2}-\mathrm{SiO}_{2}$ $(5 \mathrm{~mol} \%)$ were found to give good yield of $\mathbf{4 a}$. The $\mathrm{Yb}(\mathrm{OTf})_{3}-\mathrm{SiO}_{2}(5 \mathrm{~mol} \%)$ gave the highest yield (88\%) of $4 \mathbf{a}$ and, therefore, further studies were carried out using this as a catalyst of choice. In case of other acidic catalysts supported on silica gel such as $p \mathrm{TSA}-\mathrm{SiO}_{2}$ (71\%), $\mathrm{FeCl}_{3}-\mathrm{SiO}_{2}(59 \%)$ the yield of $\mathbf{4 a}$ was moderate but accompanied with generation of bis(indolyl)methane (5-30\%) as a side product.

Table 1. Optimization of reaction condition for model reaction generating $\mathbf{4 a}$.

\begin{tabular}{|c|c|c|c|}
\hline Catalyst & $\begin{array}{l}\text { Catalyst } \\
(\mathrm{mol} \%)\end{array}$ & Time (h) & Yield $(\%)^{\mathrm{a}}$ \\
\hline $\mathrm{SiO}_{2}$ & - & 6 & 15 \\
\hline $\mathrm{Yb}(\mathrm{OTf})_{3}$ & 5 & 4 & 72 \\
\hline $\mathrm{Zn}(\mathrm{OTf})_{2}$ & 5 & 4 & 52 \\
\hline $\mathrm{Ce}(\mathrm{OTf})_{3}$ & 5 & 4 & 71 \\
\hline $\mathrm{Cu}(\mathrm{OTf})_{2}$ & 5 & 4 & 68 \\
\hline $\mathrm{Ba}(\mathrm{OTf})_{2}$ & 5 & 4 & 50 \\
\hline $\mathrm{Yb}(\mathrm{OTf})_{3}-\mathrm{SiO}_{2}$ & 1 & 2 & 47 \\
\hline $\mathrm{Yb}(\mathrm{OTf})_{3}-\mathrm{SiO}_{2}$ & 2 & 2 & 58 \\
\hline $\mathrm{Yb}(\mathrm{OTf})_{3}-\mathrm{SiO}_{2}$ & 3 & 2 & 67 \\
\hline $\mathrm{Yb}(\mathrm{OTf})_{3}-\mathrm{SiO}_{2}$ & 4 & 2 & 74 \\
\hline $\mathrm{Yb}(\mathrm{OTf})_{3}-\mathrm{SiO}_{2}$ & 5 & 2 & 88 \\
\hline $\mathrm{Yb}(\mathrm{OTf})_{3}-\mathrm{SiO}_{2}$ & 10 & 2 & 84 \\
\hline $\mathrm{Zn}(\mathrm{OTf})_{2}-\mathrm{SiO}_{2}$ & 5 & 2 & 62 \\
\hline $\mathrm{Ce}(\mathrm{OTf})_{3}-\mathrm{SiO}_{2}$ & 5 & 2 & 81 \\
\hline $\mathrm{Cu}(\mathrm{OTf})_{2}-\mathrm{SiO}_{2}$ & 5 & 2 & 81 \\
\hline $\mathrm{Ba}(\mathrm{OTf})_{2}-\mathrm{SiO}_{2}$ & 5 & 2 & 67 \\
\hline $\mathrm{FeCl}_{3}-\mathrm{SiO}_{2}$ & 5 & 2 & 59 \\
\hline pTSA-SiO & 5 & 3 & 71 \\
\hline
\end{tabular}

a Isolated yield.

The standardized reaction conditions were used further for the synthesis of different 3-substituted indole derivatives. $^{29}$ Indole or $\mathrm{N}$-methylindole, $\mathrm{N}$ methylaniline, and a substituted or unsubstituted benzaldehyde were reacted to obtain 3-substituted indole derivatives $(\mathbf{4 a}-\mathbf{r})$. The products and their yields are summarized in Table 2. All the compounds were characterized by ${ }^{1} \mathrm{H}$ NMR, ${ }^{13} \mathrm{C} \quad \mathrm{NMR}$, and mass spectroscopy. The reaction is assumed to proceed through formation of imine through reaction of the benzaldehyde and $N$-methylaniline followed by nucleophilic attack of indole to give 3-substituted indoles as shown in Scheme 2. The structure of product is consistent with the synthesis of 3-substituted indoles via multicomponent condensation reaction of indoles, aldehyde, and amines. ${ }^{30}$

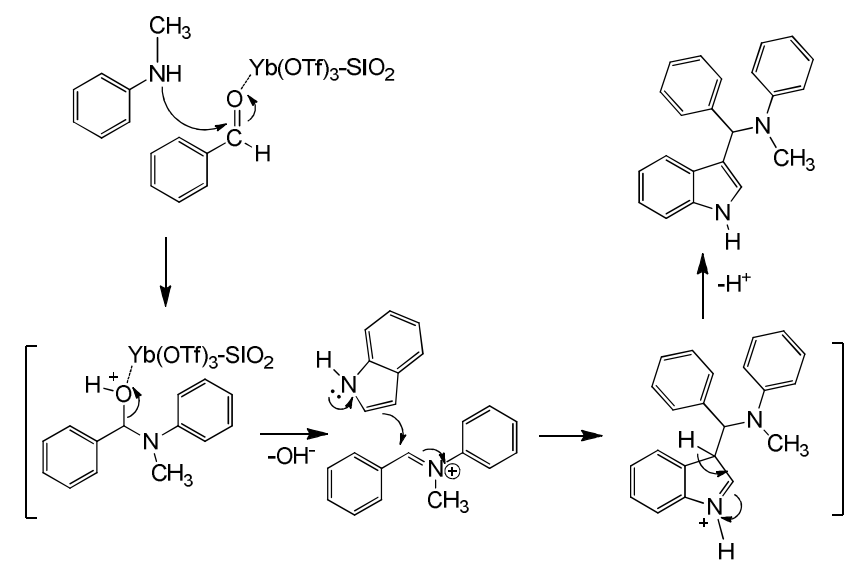

Scheme 2. Plausible mechanism for synthesis of 4 .

Table 2. Synthesis of different 3-substituted indoles (4a-r) and their Src kinase inhibitory activity.

\begin{tabular}{|c|c|c|c|c|c|}
\hline Product & $\mathrm{R}$ & $\mathrm{R}^{\prime}$ & R" & $\begin{array}{l}\text { Yield } \\
(\%)^{\mathrm{a}}\end{array}$ & $\begin{array}{c}\mathrm{IC}_{50} \\
(\mu \mathrm{M})^{\mathrm{b}}\end{array}$ \\
\hline $4 a$ & $\mathrm{H}$ & $\mathrm{H}$ & $4-\mathrm{Cl}$ & 88 & $>150$ \\
\hline $4 b$ & $\mathrm{H}$ & $\mathrm{H}$ & $4-\mathrm{CH}_{3}$ & 83 & $>150$ \\
\hline $4 c$ & $\mathrm{H}$ & $\mathrm{H}$ & $4-\mathrm{CH}_{3} \mathrm{O}$ & 86 & $>150$ \\
\hline $4 d$ & $\mathrm{H}$ & $\mathrm{H}$ & $\mathrm{H}$ & 78 & 50.6 \\
\hline $4 e$ & $\mathrm{H}$ & $\mathrm{H}$ & $4-\mathrm{OH}$ & 75 & $>150$ \\
\hline $4 f$ & $\mathrm{H}$ & $\mathrm{H}$ & $3-\mathrm{Br}, 4-\mathrm{OH}$ & 84 & $>150^{\mathrm{a}}$ \\
\hline $4 g$ & $\mathrm{H}$ & $\mathrm{H}$ & $3-\mathrm{CH}_{3} \mathrm{O}$ & 82 & $>150$ \\
\hline $4 h$ & $\mathrm{H}$ & $\mathrm{H}$ & $2,4-\mathrm{CH}_{3} \mathrm{O}$ & 81 & $>150$ \\
\hline $4 i$ & $\mathrm{H}$ & $\mathrm{CH}_{3}$ & $\mathrm{H}$ & 79 & $>150$ \\
\hline $4 j$ & $\mathrm{H}$ & $\mathrm{CH}_{3}$ & $4-\mathrm{Cl}$ & 81 & 98.3 \\
\hline $4 k$ & $\mathrm{H}$ & $\mathrm{CH}_{3}$ & $4-\mathrm{CH}_{3}$ & 82 & 60.5 \\
\hline 41 & $\mathrm{H}$ & $\mathrm{H}$ & $3-\mathrm{NO}_{2}$ & 51 & 58.3 \\
\hline $4 m$ & $5-\mathrm{Br}$ & $\mathrm{H}$ & $\mathrm{H}$ & 72 & 71.6 \\
\hline $4 n$ & $5-\mathrm{OCH}_{3}$ & $\mathrm{H}$ & $4-\mathrm{OCH}_{3}$ & 88 & 100.0 \\
\hline 40 & $5-\mathrm{OCH}_{3}$ & $\mathrm{H}$ & $4-\mathrm{CH}_{3}$ & 85 & $>150$ \\
\hline $4 p$ & $5-\mathrm{Br}$ & $\mathrm{H}$ & $4-\mathrm{CH}_{3}$ & 78 & $>150$ \\
\hline $4 q$ & $5-\mathrm{Br}$ & $\mathrm{H}$ & $4-\mathrm{OCH}_{3}$ & 80 & 106 \\
\hline $4 r$ & $5-\mathrm{OCH}_{3}$ & $\mathrm{H}$ & $4-\mathrm{Cl}$ & 83 & 87 \\
\hline
\end{tabular}

${ }^{a}$ Isolated yield; ${ }^{b}$ The concentration at which $50 \%$ of enzyme activity is inhibited.

An array of 18 diversely substituted indoles was evaluated against Src kinase. The results of Src kinase inhibitory activity of compounds $(\mathbf{4 a}-\mathbf{r})$ are shown in Table 2. Among all the screened compounds, $\mathbf{4 d}, \mathbf{4 j}, \mathbf{4 k}$, $\mathbf{4 l}$, and $\mathbf{4 r}$ showed modest inhibition of Src kinase with 
$\mathrm{IC}_{50}$ values of $50.6-98.3 \mu \mathrm{M}$. The data suggest that the presence of either electron donating or electron withdrawing groups on the phenyl ring ( $\mathrm{R}^{\prime \prime}$ position) was mostly less tolerated as shown in compounds $\mathbf{4 a - c}$, $\mathbf{4 e - i}$, and $\mathbf{4 n}-\mathbf{p}$ with $\mathrm{IC}_{50}$ value of $\geq 100 \mu \mathrm{M}$. The unsubstituted indole derivative $\mathbf{4 d}$ showed an $\mathrm{IC}_{50}$ value of $50.6 \mu \mathrm{M}$ while introduction of electron withdrawing group $-\mathrm{NO}_{2}$ at 3-position of phenyl ring (4I) exhibited comparable inhibitory activity $\left(\mathrm{IC}_{50}=58.3 \mu \mathrm{M}\right)$.

DS visualizer docking studies ${ }^{31}$ were used to study the interactions of $\mathbf{4 d}$ with the ATP binding site of the Src kinase. Compound $\mathbf{4 d}$ was superimposed on a reference anilinoquanzoline AZD05030, a dual specific c-Src/Abl kinase inhibitor ${ }^{32}$ in complex with the Src kinase (PDB 2H8H).

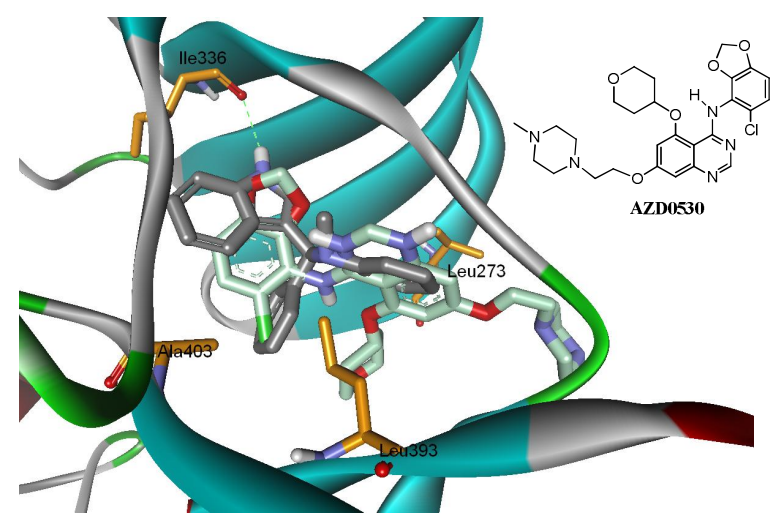

Figure 2: Comparison of interactions of $\mathbf{4 d}$ (grey) and AZD05030 (oxygens (red), nitrogens (purple), carbons (light green), chlorine (green)) in ATP binding site of the Src kinase based on molecular modeling. The compounds and side chains of amino acids (yellow) are rendered in stick styles. Compounds are in the lowest energy conformers predicted. The Figure is drawn using the Accelrys DS visualizer 2.5 system.

As can be seen from Figure 2, 4d interacts with the ATP binding pocket in slightly different orientation when compared with reference quinazoline ligand. The chloro group in reference ligand oriented towards and interacts with Ala403, whereas in $\mathbf{4 d}$ phenyl rings lie in hydrophobic binding pocket. $\mathrm{N}_{1}-\mathrm{H}$ of indole ring in compound 4d shows specific hydrogen bonding interaction with Ile336. The hydrogen bonding interaction was not observed when N1 was methylated in 4i. This interaction may have contributed to higher inhibitory activity of unmethylated compounds $\mathbf{4 d}\left(\mathbf{I C}_{50}\right.$ $=50.6 \mu \mathrm{M})$ versus $\mathrm{N} 1$-methylated analog $4 \mathbf{i}\left(\mathrm{IC}_{50}>150\right.$ $\mu \mathrm{M})$. On the other hand, $\mathrm{N}_{1}$-methylated compounds $\mathbf{4 j}$ and $\mathbf{4 k}$ exhibited improved inhibition activity versus $\mathbf{4 a}$ and $\mathbf{4 b}$, respectively (Table 2), suggesting that hydrophobic interactions of methyl with Ile336 may also contribute to modest inhibitory activity. The binding energy for $\mathbf{4 d}$ was observed as $-7.42 \mathrm{kcal} / \mathrm{mol}$ and estimated inhibition constant at $3.67 \mu \mathrm{M}$ while the reference ligand binding energy and estimated inhibition constant were $-7.36 \mathrm{kcal} / \mathrm{mol}$ and $4.01 \mu \mathrm{M}$, respectively. The RMSD from reference ligand is 1.230 Á.

The effect of the compounds on the cell proliferation of human ovarian adenocarcinoma (SKOV-3) and colon adenocarcinoma (HT-29) cancer cells that also overexpress c-Src, ${ }^{33,34}$ was also evaluated at the concentration of $50 \mu \mathrm{M}$ (Fig. 3). In general, most of the compounds were more active against SK-OV-3 cells than HT-29 cells. Indole-based SU5416 is also currently in clinical trials against ovarian cancer. Consistently compounds 4o-r inhibited the cell proliferation of both cancer cells significantly while $\mathbf{4 a}$ only inhibited SKOV-3. The 4-methylphenyl (4o and 4p) and 4methoxyphenyl (4q) indole derivatives inhibited the cell proliferation of SK-OV-3 and HT-29 cells by 70-77\% whereas 4-cholorderivatives $\mathbf{4 a}$ and $\mathbf{4 r}$ inhibited the growth of ovarian cancer cells (SK-OV-3) by approximately $72 \%$ and $77 \%$, respectively (Fig. 3). Structure-activity relationship studies suggest that the presence of bromo- or methoxy-substituent at position 5 of indole ring (R) in addition to methyl, methoxy, or chloro substitutent at as $\mathrm{R}^{\prime \prime}$ is critical for maximum anticancer activity as seen in compounds 4o-r. In general, poor correlation was observed between Src kinase inhibitory potency of the compounds and the inhibition of cell proliferation in cancer cells, suggesting that differential cellular uptake and contribution of other mechanisms in anticancer activities of these compounds. Compounds $\mathbf{4 d}$ and $\mathbf{4 r}$ that showed modest Src kinase inhibition, also inhibited the growth of SK-OV-3 by 55\% and 77\%, respectively.

In conclusion, we have developed an ecofriendly and economical method for the synthesis of 3substituted indoles by one pot three-component coupling reaction of a benzaldehyde, $\mathrm{N}$-methylaniline, and indole or $N$-methylindole using $\mathrm{Yb}(\mathrm{OTf})_{3}-\mathrm{SiO}_{2}$ as catalyst. To the best of our knowledge, this is the first report of the synthesis and evaluation of 3-substituted indole derivatives as $\mathrm{Src}$ kinase inhibitors and anticancer agents. The compounds $\mathbf{4 d}, \mathbf{4 j}, \mathbf{4 k}, \mathbf{4 l}$, and $\mathbf{4 r}$ showed modest inhibition of Src kinase while compounds 4o-r inhibited the cell proliferation of ovarian and colon cancer cells significantly. Structure-activity relationship studies revealed the importance of the presence of a substituent at position 5 of indole ring $(\mathrm{R})$ for anticancer activity. This study provides insights for further optimizing of substituted indoles for the discovery of the Src kinase inhibitors and/or anticancer agents.

\section{Acknowledgements}

We acknowledge University Grant Commission (UGC), New Delhi and the American Cancer Society Grant \#RSG-07-290-01-CDD for the financial support. We 


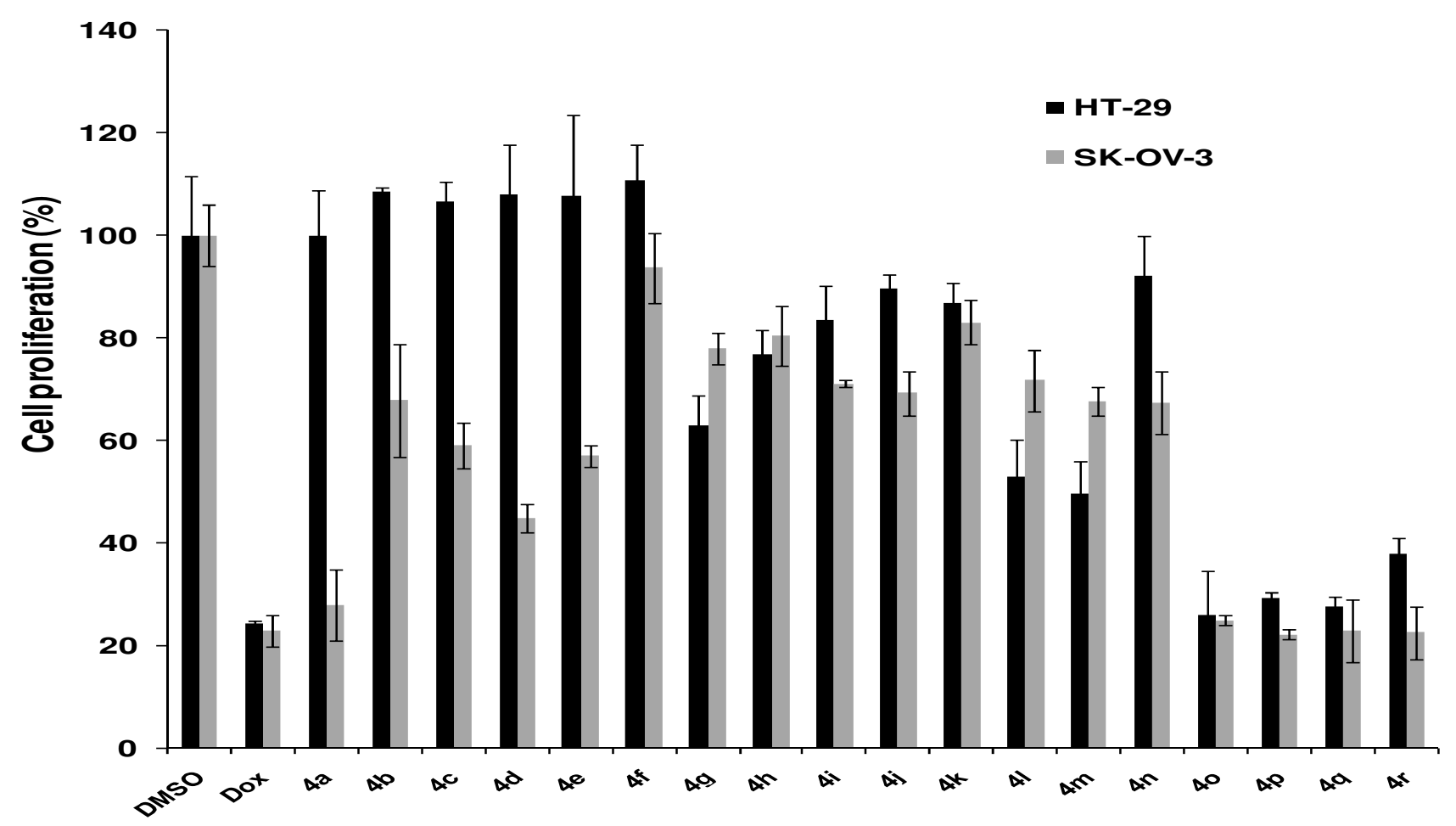

Figure 3. Inhibition of HT-29 and SK-OV-3 cell proliferation by compounds $4 \mathbf{a}-\mathbf{r}(50 \mu \mathrm{M})$ after $72 \mathrm{~h}$ incubation. The results are shown as the percentage of the control DMSO that has no compound (set at 100\%). All the experiments were performed in triplicate.

\section{Supplementary data}

Supplementary data (experimental procedures and characterization of compounds) can be found in the online version of this article.

\section{References and notes}

1. Morris, S. A.; Andersen, R. J. Tetrahedron 1990, 46, 715 .

2. Mancini, I.; Guella, G.; Pietra, F.; Debitus, C.; Waikedre, J. Helv. Chim. Acta 1996, 79, 2075.

3. Bokesch, H. R.; Pannell, L. K.; McKee, T. C.; Boyd, M. R. Tetrahedron Lett. 2000, 41, 6305.

4. Casapullo, A.; Bifulco, G.; Bruno, I.; Riccio, R. J. Nat. Prod. 2000, 63, 447.

5. Ford, J.; Capon, R. J. J. Nat. Prod. 2000, 63, 1527.

6. Cutignano, A.; Bifulco, G.; Bruno, I.; Casapullo, A.; Gomez-Paloma, L.; Riccio, R. Tetrahedron 2000, 56, 3743.

7. Olgen, S.; Akaho, E.; Nebioglu, D. J. Enzyme Inhib. Med. Chem. 2003, 18, 485.

8. Ahmad, A.; Sakr, W. A.; Rahman, K. M. Curr Drug Targets 2010, 11, 652.

9. Liou, J. P.; Chang, Y.-L.; Kuo, F.-M.; Chang, C.W.; Tseng, H.-Y.; Wang, C.-C.; Yang, Y.-N.; Chang, J.-Y.; Lee, S.-J.; Hsieh, H.-P. J. Med. Chem. 2004, 47, 4247.
10. Kılıç, Z.; İşgör, Y. G.; Ölgen, S. Chem. Biol. Drug Des. 2009, 74, 397.

11. Showalter, H. D. H.; Sercel, A. D.; Leja, B. M.; Wolfangel, C. D.; Ambroso, L. A.; Elliott, W. L.; Fry, D. W.; Kraker, A. J.; Howard, C. T.; Lu, G. H.; Moore, C. W.; Nelson, J. M.; Roberts, B. J.; Vincent, P. W.; Denny, W. A.; Thompson, A. M. J. Med. Chem. 1997, 40, 413.

12. Sun, L.; Tran, N.; Tang, F.; App, H.; Hirth, P.; McMahon, G.; Tang, C. J. Med. Chem. 1998, 41, 2588.

13. Sun, L.; Tran, N.; Liang, C.; Hubbard, S.; Tang, F.; Lipson, K.; Schreck, R.; Zhou, Y.; McMahon, G.; Tang, C. J. Med. Chem. 2000, 43, 2655.

14. Mohammadi, M.; McMahon, G.; Sun, L.; Tang, C.; Hirth, P.; Yeh, B. K.; Hubbard, S. R.; Schlessinger, J. Science 1997, 276, 955.

15. Kumar, A.; Wang, Y.; Lin, X.; Sun, G.; Parang, K. ChemMedChem 2007, 2, 1346.

16. Thomas, S. M.; Brugge, J. S. Annu. Rev. Cell Dev. Biol. 1997, 13, 513.

17. Frame, M. C. Biochim. Biophys. Acta 2002, 114, 1602.

18. Summy, J. M.; Gallick, G. E. Cancer Metastasis Rev. 2003, 22, 337.

19. Yeatman, T. J. Nat. Rev. Cancer 2004, 4, 470.

20. Lee, D.; Gautschi, O. Clin. Lung Cancer 2006, 7, 381. 
21. Parang, K.; Sun, G. Expert Opin. Ther. Pat. 2005, 15,1183 .

22. Ye, G.; Tiwari, R.; Parang, K. Curr. Opin. Investig. Drugs 2008, 9, 605.

23. Serrels, A.; Macpherson, I. R. J.; Evans, T. R. J.; Lee, F. Y.; Clark, E. A.; Sansom, O. J.; Ashton, G. H.; Frame, M. C.; Brunton, V. G. Mol. Cancer Ther. 2006, 5, 3014.

24. Jallal, H.; Valentino, M. L.; Chen, G.; Boschelli, F.; Ali, S.; Rabbani, S. A. Cancer Res. 2007, 67, 1580.

25. Huang, F.; Reeves, K.; Han, X.; Fairchild, C.; Platero, S.; Wong, T. W.; Lee, F.; Shaw, P.; Clark, E. Cancer Res. 2007, 67, 2226.

26. Finn, R. S.; Dering, J.; Ginther, C.; Wilson, C. A.; Glaspy, P.; Tchekmedyian, N.; Slamon, D. J. Breast Cancer Res. Treat. 2007, 105, 319.

27. Kumar, A.; Rao, M. S.; Rao, V. K. Aust. J. Chem. 2010, 63, 1538. (b) Kumar, A.; Rao, M. S.; Rao, V. K. Aust. J. Chem. 2010, 63, 135.

28. Kumar, A.; Ahmad, I.; Chhikara, B. S.; Tiwari, R.; Mandal, D.; Parang, K. Bioorg. Med. Chem. Lett. 2011, 21, 1342; (b) Kumar, D.; Reddy, V. B.; Kumar, A.; Mandal, D.; Tiwari, R.; Parang, K. Bioorg. Med. Chem. Lett. 2011, 21, 449; (c) Sharma, D.; Bhatia, S.; Sharma, R. K.; Tiwari, R.; Olsen, C. E.; Mandal, D.; Lehmann, J.; Parang, K.; Parmar, V. S.; Prasad, A. S. Biochimie 2010, 92, 1164; (d) Tiwari, R.; Brown, A.; Narramaneni, S.; Sun, G.; Parang, K. Biochimie 2010, 92, 1153; (e) Kumar, A.; Ye, G.; Wang, Y.; Lin, X.; Sun, G.; Parang, K. J. Med. Chem. 2006, 49, 3395; (f) Nam, N.-H.; Ye, G.; Sun, G.; Parang, K. J. Med. Chem. 2004, 47, 3131.

29. General procedure for preparation of 3-substituted indoles: To a solution of $N$-methylaniline $(114 \mathrm{mg}$, $1.2 \mathrm{mmol})$ and a benzaldehyde $(1.0 \mathrm{mmol})$ in acetonitrile $(10 \mathrm{~mL})$ was added $\mathrm{Yb}(\mathrm{OTf})_{3}-\mathrm{SiO}_{2}(30$ $\mathrm{mg}$ on $300 \mathrm{mg} \mathrm{SiO}_{2}$ ). The reaction mixture was stirred at room temperature. After $30 \mathrm{~min}$, indole or $N$-methylindole $(0.71 \mathrm{mmol})$ was added to the reaction and the mixture was allowed it to stir for additional $90 \mathrm{~min}$. The progress of reaction was monitored by TLC. After completion of the reaction $\mathrm{Yb}(\mathrm{OTf})_{3}-\mathrm{SiO}_{2}$ was removed by filtration and washed with ethyl acetate $(3 \times 5 \mathrm{~mL})$. The filtrate was dried over anhydrous sodium sulfate and concentrated to obtain the crude product, which was purified by column chromatography on silica gel (100-200 mesh) using ethyl acetate/hexane as eluents to yield a pure product $(\mathbf{4 a}-\mathbf{r})$. All the compounds were characterized by ESI-MS, ${ }^{1} \mathrm{H}$ NMR and ${ }^{13} \mathrm{C}$ NMR spectroscopic data.

30. (a) Rihari, P.; Singh, V. K.; Bhunia, D. C.; Yadav, J. S. Tetrahedron Lett. 2009, 27, 376; (b) Das, B.; Kumar, N. J.; Kumar, S. A.; Damodar, K. Synthesis 2010, 6, 914.

31. Morris, G. M.; Huey, R.; Lindstrom, W.; Sanner, M. F.; Belew, R. K.; Goodsell, D. S.; Olson, A. J. J. Comp. Chem. 2009, 30, 2785.

32 Hennequin, L. F.; Allen, J.; Breed, J.; Curwen, J.; Fennell, M.; Green, T. P.; Lambert-van der Brempt C.; Morgentin, R.; Norman, R. A.; Olivier, A.; Otterbein, L.; Plé, P. A.; Warin, N.; Costello, G. J. Med. Chem. 2006, 49, 6465.

33. Belches-Jablonski, A. P.; Biscardi, J. S.; Peavy, D. R.; Tice, D. A.; Romney, D. A.; Parsons, S. J. Oncogene, 2001, 20, 1465.

34. Budde, R. J.; Ke, S.; Levin, V. A. Cancer Biochem. Biophys. 1994, 14, 171. 